\section{In Vitro Inhibitory Activity of Antimicrobial Peptides Cecropin, $\alpha$-Thionin DB4, and $\gamma$-Thionin RsAFP1 Against Several Pathogens of Strawberry and Highbush Blueberry}

\author{
F.A. Hammerschlag ${ }^{1}$ \\ Fruit Laboratory, Agricultural Research Service, U.S. Department of \\ Agriculture, 10300 Baltimore Avenue, Beltsville, MD 20705
}

Additional index words. Botryosphaeria dothidea, Botrytis, Colletotrichum, Fragaria $\times$ ananassa, Monilinia vaccinii-corymbosi, Phytophthora fragariae, Vaccinium corymbosum, Xathomonas fragariae

\begin{abstract}
As part of a program to develop transgenic highbush blueberry (Vaccinium corymbosum L.) and strawberry (Fragaria xananassa Duchesne) cultivars with increased levels of disease resistance, we have investigated the feasibility of introducing genes for the antimicrobial peptides cecropin B and MB39, $\alpha$-thionin DB4 (DB4) and $\gamma$-thionin RsAFP1 (RsAFP1) by testing the effects of these peptides on several important pathogens of these two crop species. A thin-layer plate bioassay was conducted with these peptides and the pathogens Botrytis cinerea (Pers.ex. Fr.), Botryosphaeria dothidea (Mouq.ex. Fr.) Ces \& de Not., Colletotrichum acutatum Simmonds, C. gloeosporioides (Penz.) Penz.et Sacc., $C$. fragariae Brooks, Monilinia vaccinii-corymbosi Reade (Honey), Phytophthora fragariae Hickman and Xanthomonas fragariae Kennedy and King. The minimum lethal concentration $(\mu \mathrm{M})$ for cecropin ranged from 0.02 for $X$. fragariae strains 10 and 128 to 72.8 for C. gloeosporioides isolate Akp1. For DB4, the minimum inhibitory concentration $(\mu \mathrm{M})$ ranged from 0.03 for $X$. fragariae strain 6 to 87.2 for $B$. cinerea isolate cc. For RsAFP1, the minimum inhibitory concentration ( $\mu \mathrm{M})$ ranged from 0.13 for $X$. fragariae strain 6 to 61.4 for M. vaccinii-corymbosi isolate $9423-x-45$. These results indicate that introducing genes for either cecropin, DB4 or RsAFP1 into strawberry may be useful for controlling bacterial angular leaf spot disease caused by $X$. fragariae.
\end{abstract}

Cultivated strawberry and highbush blueberry are hosts to a large and diverse number of pathogens and pests including fungi, bacteria, viruses, phytoplasma, nematodes, and arthropods. The pathogens that are considered major obstacles to maintaining or increasing strawberry production include $P$. fragariae, $\mathrm{Col}$ letotrichum spp., B. cinerea and X. fragariae (Hancock et al., 1991; Maas et al., 1995; Roberts et al., 1995), and M. vaccinii-corymbosi, $B$. dothidea and C. gloeosporioides for blueberry (Luby et al., 1991). There is no effective chemical control for X. fragariae (Maas et al., 1995), and although pesticides are currently used to control the above mentioned fungal pathogens, the need to reduce production costs, coupled with concerns over the chemical impact on the environment and safety of food products, increased resistance of pests and pathogens to pesticides, failure of chemical companies to renew registrations, and phasing out of pesticides (Cornelissen and Melchers, 1993;

Received for publication 4 Nov. 2003. Accepted for publication 11 Dec. 2003. Thanks to Stephanie Ray, Thelma Ayensu and Kate Scutt for technical assistance. Use of a company or product name does not imply approval or recommendation of the product to the exclusion of others, which may also be suitable.

${ }^{1}$ Supervisory research plant physiologist and research leader; e-mail hammersf@ba.ars.usda.gov.
Gilpatrick, 1983; Wilhelm, 1999) suggest that introducing disease resistance into fruit crops may be a viable approach to controlling crop losses. Although genetic sources of resistance to disease exist for blueberry and strawberry, the many generations of hybridization and selection required to produce commercial quality fruit with adaptive traits obtained from noncommercial genotype are a severe impediment to crop improvement (Hancock et al., 1991; Luby et al., 1991). Over the past 10 years, some groundwork has been laid for utilizing molecular approaches to improve small fruit crops (Hokanson and Maas, 2001; Rowland and Hammerschlag, 2003), however, to date there are still only a few examples of using gene transfer to introduce horticulturally useful genes into strawberry (Graham et al., 1995, 1997; Mathews et al., 1995; Owens et al., 2002) and only preliminary transformation studies have been conducted on blueberry (Cao et al., 1998, 2003; Graham et al., 1996).

Increased disease resistance to both fungal and bacterial pathogens has been achieved in a range of plants following the introduction of genes encoding the small antimicrobial proteins $\alpha$-thionin (Carmona et al., 1993), $\gamma$ thionin (a plant defensin) (Terras et al., 1995), and cecropin, (Jaynes et al., 1993; Liu et al., 2001). The thionins, found in many plants, are small proteins, only $\approx 50$ amino acid units in length, that display varying levels of activity against a broad range of plant pathogenic fungi and some bacterial pathogens (Bohlmann et al., 1988; Moreno et al., 1994; Terras et al, 1995). Cecropins, found in the giant silk moth (Hyalophora cecropia) (Boman and Hultmark, 1987), comprise a family of naturally occurring lytic peptides that exhibit both antibacterial and antifungal activity (Li and Gray, 2003; Mills and Hammerschlag, 1993; Owens and Huette, 1997). Because of their broad spectrum antimicrobial activity and because they exhibit little cytotoxicity to animal and plant cells (Bechinger, 1997; Sharma et al., 2000), the cecropins are particularly attractive candidates for developing transgene-induced resistance. In the present study, we report on the effect of these peptides on the growth of a range of pathogens of strawberry and blueberry as a prerequisite to using a transformation approach to generate increased levels of disease resistance in these crops.

\section{Materials and Methods}

Maintenance of plant pathogens. B. cinerea isolates cc and wk (obtained from W. Conway, USDA-ARS, Beltsville, Md.), B. dothidea isolates \#3 and \#5 (obtained from Jim Polashock, USDA-ARS, Chatsworth, N.J.), M. vacciniicorymbosi isolates 9520-X-7, 963-X-Snss, 9423-X-45 (obtained from Mark Ehlenfeldt, USDA-ARS, Chatsworth) were maintained on Difco potato dextrose agar (PDA) at $4{ }^{\circ} \mathrm{C}$ in the dark. During the bioassay period, 2 to $3-\mathrm{mm}$ diameter hyphal plugs were transferred weekly to PDA and incubated in the dark at $25^{\circ} \mathrm{C}$.

Colletotrichum acutatum isolates cal c and Goff, C. fragariae isolate Fla 2, and C. gloeosporioides isolates Akp-1 and 162 (obtained as silica gel cultures from Barbara Smith, USDA-ARS, Poplarville, Miss.) were stored at $4 \% \mathrm{C}$ in the dark. During the bioassay period, fungal-coated silica gel was transferred to PDA and then 2-3 mm hyphal tips transferred weekly to fresh PDA plates. Petri plates were incubated at $25{ }^{\circ} \mathrm{C}$ under continuous cool white fluorescent light. About every 6 to 8 weeks these three Colletotrichum spp. were reisolated from silica gel cultures.

Phytophthorafragariae (obtained from John Maas, USDA-ARS, Beltsville) was maintained in the dark at $4{ }^{\circ} \mathrm{C}$ on petri plates containing a soil and rhizosphere microoganizsm isolation medium (dRSM) (Buyer, 1994). For bioassays, $P$. fragariae was transferred weekly to dRSM and maintained in the dark at $25^{\circ} \mathrm{C}$.

Xanthomonas fragariae strains 6, 10, 128, and ATCC33239 (obtained from John Hartung, USDA-ARS, Beltsville) were maintained at $4{ }^{\circ} \mathrm{C}$ on SPA medium (Hayward, 1960) consisting of (in $\mathrm{g} \cdot \mathrm{L}^{-1}$ ) 20 sucrose, 5 peptone, $0.5 \mathrm{~K}_{2} \mathrm{HPO}_{4}, 0.25 \mathrm{MgSO}_{4} \cdot 7 \mathrm{H}_{2} \mathrm{O}, 15$ Bactoagar. For bioassays, a loopful of bacteria was streaked onto SPA medium and incubated at $28^{\circ} \mathrm{C}$ in the dark for 5 to $7 \mathrm{~d}$ to provide cells for inoculum.

Peptides. Cecropin B was purchased from Bachem California (Torrance, Calif.). Cecropin MB39 and thionins RsAFP1 and DB4 were obtained from Lowell Owens, USDA-ARS, 
Beltsville, who synthesized these peptides as reported (Owens and Heutte, 1997).

Thin-agarose radial diffusion assay. The method of Hultmark et al. (1983) as modified by Nordeen et al. (1992) was used to assay antimicrobial activity of selected peptides. Petri plates were prepared by adding $6 \mathrm{ml}$ of the media specified above for each pathogen, but with $1 \%$ seaplaque agarose instead of agar and without $\mathrm{MgSO}_{4} \cdot 7 \mathrm{H}_{2} \mathrm{O}$ for $X$. fragariae. To test peptides on fungal pathogens and $P$. fragariae, an upside-down plug of fungal mycelia $(7 \mathrm{~mm}$ in diameter), taken from the edge of actively growing culture, was placed onto the center of the solidified agarose. Petri plates were wrapped with parafilm, incubated in the dark at $25^{\circ} \mathrm{C}$ until the radius of the fungal colony was grown out $1 \mathrm{~cm}$ from the original inoculum $(0.5 \mathrm{~cm}$ for $P$. fragariae). Wells $2 \mathrm{~mm}$ in diameter were then positioned $1 \mathrm{~cm}$ from the periphery of the mycelia and two microliters of test protein (1 $\mu \mathrm{g} \cdot \mu \mathrm{L}^{-1}$ ) dissolved in water was added to each well. For assays with $X$. fragariae, the bacterium was grown overnight in liquid SPA medium, adjusted to an optical density of 0.165 at 620 $\mathrm{nm}$ to give a standard inoculum of $\approx 4 \times 10^{8}$ colony forming units $(\mathrm{CFU}) / \mathrm{mL}$, diluted with sterile distilled water and added to cooled assay medium to give a final concentration of $1 \times 10^{6}$ $\mathrm{cfu} / \mathrm{mL}$. Wells were then positioned $\approx 2 \mathrm{~cm}$ from the center of the petri plate and the test solutions added as above.

Petri plates were wrapped with parafilm and incubated in the dark at $25{ }^{\circ} \mathrm{C}$ with the exception of $X$. fragariae which was incubated at $28^{\circ} \mathrm{C}$ in the dark. Minimum lethal (bacteria) or minimum inhibitory (all other pathogens) concentrations were calculated from inhibition zone diameters measured when the pathogens reached the control well containing bovine serum albumin, according to the mathematical model of Hultmark et al. (1983), where minimum inhibitory or lethal concentration $(C)=0.468 \mathrm{n} / \mathrm{ad}^{2}[\mathrm{n}=$ nmole of peptide in well, $\mathrm{a}=$ agarose depth $(0.11 \mathrm{~cm})$, and $\mathrm{d}=$ zone diameter of inhibition (cm)]. After scoring, mycelia continued to grow at reduced rates into the inhibition zones, hence the term minimum inhibitory concentration is used to describe the fungal and $P$. fragariae response rather than minimum lethal concentration descriptive of the bacterial response. Each assay consisted of two replicate petri plates with one well per test solution per plate. Assays were conducted a minimum of three times.

\section{Results and Discussion}

Cecropin and thionins DB4 and RsAFP1 were all highly inhibitory (at sub-micromolar levels) to $X$. fragariae isolates, but not to any of the three Colletotrichum species, P.fragariae or to isolates of B. cinerea, B. dothidea and $M$. vaccinii-corymbosi (Table 1). The minimum lethal concentration of these peptides against $X$. fragariae ranged from $0.02 \mu \mathrm{M}$ for cecropin $\mathrm{B}$ against strains 10 and 128 to $0.04 \mu \mathrm{M}$ for DB4 against strains 10 and 128 . The minimum inhibitory concentration of these peptides against the fungal pathogens ranged from $10.6 \mu \mathrm{m}$ for cecropin MB39 against $B$. cinerea isolate wk to $87.2 \mu \mathrm{m}$ for DB4 against $C$. acutatum isolate calc and $B$. cinerea isolate cc.

Cecropin B and its structural analog MB39 (Boman and Hultmark, 1987; Owens and Huette, 1997)) were selected for these studies over Shiva-1, another cecropin B structural analog with potent lytic activity (Jaynes et al., 1993), because previous studies showed cecropin B and Shiva-1 to be equally toxic to $X$. campestris pv. campestris (Jaynes et al., 1993), and because cecropin B showed cytotoxicity in the micromolar range against a range of bacteria and fungi (Alan and Earle, 2002; Mills and Hammerschlag, 1993; Owens and Huette, 1997). Recently, cecropin B was found to be significantly more effective than Shiva-1 in inhibiting growth of the bacterial pathogens Xylella fastidiosa and Agrobacterium tumefaciens (Li and Gray, 2003).

Cecropin MB39 was initially used for our studies, but cecropin B was substituted when our MB39 supply was exhausted. MB 39 differs from the latter by 1) substitution of Val for Met, to eliminate a translational start codon in the corresponding engineered gene, 2)

Table 1. In vitro inhibitory or lethal activity of cecropins B and MB39 and thionins DB4 and RsAFP1 against several pathogens of blueberry and strawberry. ${ }^{2}$

\begin{tabular}{|c|c|c|c|c|c|}
\hline \multirow[b]{2}{*}{ Plant pathogen } & \multirow{2}{*}{$\begin{array}{l}\text { Isolate/ } \\
\text { strain }\end{array}$} & \multicolumn{4}{|c|}{ Minimum inhibitory or lethal concn $(\mu \mathrm{M})$} \\
\hline & & Cecropin B & Cecropin MB39 & DB4 & RsAFP1 \\
\hline \multirow[t]{2}{*}{ Botrytis cinerea } & $\mathrm{cc}$ & --- & $28.8 \pm 9$ & $87.2 \pm 0$ & $59.8 \pm 14$ \\
\hline & wk & --- & $10.6 \pm 2$ & $38.4 \pm 24$ & $18.5 \pm 8$ \\
\hline \multirow[t]{2}{*}{ Botryospaeria dothidea } & \#3 & --- & $16.7 \pm 1$ & $21.4 \pm 4$ & $29.7 \pm 3$ \\
\hline & \#5 & --- & $-20.1 \pm 5$ & $22.0 \pm 4$ & $21.3 \pm 5$ \\
\hline \multirow{2}{*}{ Colletotrichum acutatum } & $\mathrm{cal} \mathrm{c}$ & --- & $-27.1 \pm 10$ & $87.2 \pm 0$ & $13.9 \pm 2$ \\
\hline & Goff & --- & $22.2 \pm 3$ & $71.1 \pm 16$ & $24.4 \pm 5$ \\
\hline C. fragariae & Fla 2 & --- & $31.8 \pm 7$ & $62.8 \pm 25$ & $23.1 \pm 5$ \\
\hline \multirow[t]{2}{*}{ C. gloeosporioides } & Akp-1 & --- & $72.7 \pm 28$ & $27.5 \pm 6$ & $13.9 \pm 2$ \\
\hline & 162 & --- & $47.5 \pm 27$ & $29.0 \pm 10$ & $13.9 \pm 2$ \\
\hline \multirow[t]{3}{*}{ Monilinia vaccinii-corymbosi } & $9423-\mathrm{x}-45$ & --- & $41.9 \pm 14$ & $61.4 \pm 12$ & $55.8 \pm 16$ \\
\hline & $9520-x-7$ & --- & $21.5 \pm 12$ & $37.3 \pm 20$ & $18.1 \pm 10$ \\
\hline & 963-X-Snss & --- & $54.1 \pm 25$ & $16.4 \pm 2$ & $18.1 \pm 4$ \\
\hline Phytophthora fragariae & & $63.6 \pm 19$ & --- & --- & --- \\
\hline Xanthomonas fragariae & 6 & $0.03 \pm 0$ & --- & $0.03 \pm 0$ & $0.1 \pm 0.01$ \\
\hline X. fragariae & 10 & $0.02 \pm 0$ & --- & $0.04 \pm 0.01$ & $0.1 \pm 0.02$ \\
\hline$X$. fragariae & 128 & $0.02 \pm 0$ & --- & $0.04 \pm 0$ & $0.2 \pm 0.07$ \\
\hline X. fragariae & ATCC33239 & $0.03 \pm 0$ & --- & $0.05 \pm 0$ & $0.2 \pm 0.02$ \\
\hline
\end{tabular}

${ }^{2}$ Values are the means and standard errors of two replicate plates from a minimum of three replicate experiments. the addition of a tripeptide to the $\mathrm{N}$ terminus, to create a signal-peptide cleavage site, and 3) the substitution of a Gly residue for the amide group at the $\mathrm{C}$ terminus, Gly being the post-translational source of the amide group in cecropin (Owens and Huette, 1997). These two peptides have been shown to be equally active against a number of plant pathogens, but the MB39 form is potentially more useful for combating bacterial plant pathogens, because it is less susceptible to degradation by plant proteases in the intercellular fluid (Owens and Huette, 1997). The cecropin MB39 results suggest that cecropin MB39 could potentially be used to control $X$. fragariae. Other studies have demonstrated that MB39 transgenic tobacco (Nicotiana tabacum) (Huang et al., 1997) and apple (Malus $\times$ domestica) (Liu et al., 2001) exhibit increased levels of resistance to Pseudomonas syringae and Erwinia amylovora, respectively; however, its gene will need to be tailored to reduce the rate of degradation of the protein in strawberry.

Cecropin B was initially selected for testing against $P$. fragariae because it was shown to be toxic to P. infestans (Owens and Heutte, 1997) as well as to a range of $P$. infestans genotypes (Owens, unpublished data); however, it was not effective in inhibiting growth of $P$. fragariae. These findings point out the difficulty of using this approach for disease control since the introduction of defense genes does not generally provide broad spectrum control (Stuiver and Custers, 2001), either because of 1) differential sensitivity of the same or similar pathogens to the same gene product or 2) because of different defense systems within the different crops. Another example of the first was the differential response of the B. cinerea isolates and the $\mathrm{Mo}$ nilinia vaccinii-corymbosi isolates to the same antimicrobial peptide in the present study (Table 1). An example of the second was encountered when the introduction of a chitinase gene into cucumber and carrot resulted in increased resistance only in carrot, even when the same pathogen was used to challenge the two transgenic crops (Punja and Raharjo, 1996).

The two thionins, DB4 and RsAFP1, were selected for this study because they were shown to be active against a range of fungi (Bohlmann et al., 1988; Terras et al., 1992, 1995). Although none of the fungi tested were highly sensitive to either of these two peptides, differential sensitivity of isolates of $M$. vaccinii-corymbosi and B. cinerea to each peptide was observed (Table 1).

Both DB4 and RsAFP1 were as toxic to $X$. fragariae as cecropin B (Table 1). This is in contrast to Terras et al. (1992) who found most bacteria insensitive to defensins. However, several bacteria such as Bacillus subtilis (Osborn et al., 1995), and Pseudomonas solanacearum and Clavibacter michiganisis (Moreno et al., 1994) have been shown to be sensitive to plant defensins. Of significance is that both the thionins and cecropin MB39 were equally effective against the four $X$. fragariae representing four genotypic strain groups as defined by repetitive element PCR-based assays (Pooler et al., 1996), and thus, these peptides are good candidates for insertion into 
strawberry to control bacterial angular leaf spot disease. Bacterial angular leafspot disease of strawberry has become increasingly important to strawberry fruit and plant production in Canada, the United States, as well as in other countries (Maas et al., 1995). Under certain conditions it can cause considerable crop loss (Roberts et al., 1995). The seriousness of the disease has caused many countries to close their borders to importation of plants from regions which have this disease problem (Calzolari, 1994). Because the mode of action of all three peptides is different, a strategy to pyramid these transgenes might be a viable approach to generating a more durable and broad-spectrum resistance in strawberry. Gene pyramiding via genetic engineering for enhanced disease resistance has been reported (Jach et al., 1995; Maqbool et al., 2001).

\section{Conclusions}

This study suggests a strategy for control of bacterial angular leaf spot disease by introducing the antimicrobial peptides cecropin, DB4 and RsAFP1 into strawberry. Although these peptides were not highly active against the important fungal pathogens of strawberry and blueberry, these are but a few of the wide range of antifungal plant proteins that have been identified, which include ribosome-inactivating proteins (Leah et al., 1991), chitin-binding proteins of the PR4 and hevein types (Hejgaard et al, 1992; van Parijs et al., 1991), thaumatinlike proteins (Hejgaard et al., 1991; Vigers et al, 1991), lipid transfer proteins (Monila et al., 1993), and other cysteine-rich proteins of low molecular weight including the $\beta$-thionins (Garcia-Olmedo et al., 1992).

\section{Literature Cited}

Alan,A.R. andE.D.Earle. 2002. Sensitivity of bacterial and fungal plant pathogens to the lytic peptides, MSI-99, magainin II, and cecropin B. MPMI 15:701-708.

Bechinger, B. 1997. Structure and functions of channelforming peptides:Maganin, cecropins, melittin and alamethicin. J. Membr. Biol. 156:197-211.

Boman,H.G. and D. Hultmark. 1987. Cell-free immunity in insects. Annu. Rev. Microbiol. 41:103-126.

Bohlmann, H., S. Clausen, S. Behnke, H. Giese, C. Hiller, U. Reimann-Phillipp, G. Schrader, V. Barkholt, and K. Apel. 1988. Leaf-specific thionins of barley-A novel class of cell wall proteins toxic to plant-pathogenic fungi and possibly involved in the defense mechanism of plants. EMBO J. 7:1559-1565.

Buyer,J.S. 1994. A soil and rhizoshpere microoganismisolation and enumeration medium that inhibits Bacillus mycoides. Appl. Environ. Microbiol. 61:1839-1842.

Calzolari, A. 1994. Xanthomonas fragariae: Detection methods in strawberry plants. OEPP/EPPO Bull. 24:343-346.

Cao, X., Q. Liu, L.J. Rowland and F.A. Hammerschlag. 1998. GUS expression in blueberry (Vaccinium spp.) Factors influencing Agrobacterium-mediated gene transfer efficiency. Plant Cell Rpt. 18:266-270.

Cao, X., I. Fordham, L. Douglass, and F.A. Hammerschlag. 2003. Sucrose level influences micropropagation and gene delivery into leaves from in vitro propagated highbush blueberry shoots. Plant Cell Tiss. Org. Cult. 75:255-259.

Carmona, M.J., A. Molina, J.A. Fernandex, J.J. LopezFando, and F. Garcia-Olmedo. 1993. Expression of the $\alpha$-thionin gene from barley in tobacco confers enhanced resistance to bacterial pathogens. Plant J. 3:457-462
Cornellissen, B.J. and L.S. Melchers. 1993. Strategies for control of fungal diseases with transgenic plants. Plant Physiol. 101:709-712.

Garcia-Olmedo, F., M.J.Carmona, J.J.Lopez-Fando, J.A Fernandez, A. Castagnaro, A. Molina, C. HernandezLucas, and P. Carbonero. 1992. Characterization and analysis of thionin genes, p. 283-302. In: T. Boller and F. Meins (eds.). Genes involved in plant defense. Springer-Verlag, New York.

Gilpatrick, J.D. 1983. Management of resistance in plant pathogens, p. 735-767. In: G. Georghiou and S. Saito (eds.). Pest resistance to pesticides, Plenum Press, New York.

Graham, J., R.J. McNicol, and K. Greig. 1995. Towards genetic based insect resistance in strawberry using the cowpea trypsin inhibitor gene. Ann. Appl. Biol. 127:163-173.

Graham, J., K. Greig, and R.J. McNicol.. 1996. Transformation of blueberry without antibiotic selection. Ann. Appl. Biol. 128:557-564.

Graham, J., S.C. Gordon, and R.J. McNicol. 1997. The effect of the CpTi gene in strawberry against attack by vine weevil (Otiorhynchus sulcatus F. Coleoptera: Curculionidae). Ann. Appl. Biol. 131:133-139.

Hancock, J.F., J.L. Maas, C.H. Shanks, P.J. Breen, and J.J. Luby. 1991. Strawberries (Fragaria). Acta Hort. 290:491-546.

Hayward, A.C. 1960. A method for characterizing Pseudomonas solanacearum. Nature (London) 186:405-406.

Hejgaard, J., S. Jacobsen, and I. Svendsen. 1991. Two antifungal thaumatin-like proteins from barley grain. FEBS Lett. 291:127-131.

Hejgaard, J., S. Jacobsen, S,E. Bjorn, and K.M Kragh. 1992. Antifungal activity of chitin-binding PR-4 type proteins from barley grain and stressed leaf. FEBS Lett. 301:389-392.

Hokanson, S. and J. Maas. 2001. Strawberry biotechnology. Plant Breeding Rev. 21:139-180.

Huang, Y, R.O. Nordeen, M. Di, L.D. Owens, and J.H. McBeath. 1997. Expression of an engineered cecropin gene cassette in transgenic tobacco plants confers disease resistance to Pseudomonas syringae pv. tabaci. Phytopathology 87:494-499.

Hultmark, D., A. Engstrom, K. Andersson, H. Steiner, H. Bennich, and H.G. Boman. 1983. Insect immunity. Attacins, a family of antibacterial proteins from Hyalophora cecropia. EMBO J. 2:571-576.

Jach, G., B. Gornhardt, J. Mundy, J. Logemann, E. Pinsdorf, R. Leah, J. Schell, and C. Maas. 1995. Enhanced quantitative resistance against fungal disease by combinatorial expression of different barley antifungal proteins in transgenic tobacco. Plant J. 8:97-109.

Jaynes, J.M., P. Nagpala, L. Destefano-Beltran, J.H. Huang, J.-H. Kim, T. Denny, and S. Cetiner. 1993. Expression of a cecropin lytic peptide analog in transgeneic tobacco confers enhanced resistance to bacterial wilt caused by Pseudomonas solanacearum. Plant Sci. 89:43-53.

Leah, R., H. Tommerup, I. Svendsen, and J. Mundy. 1991. Biochemical and molecular characterization of three barley seed proteins with antifungal activity. J. Biol. Chem. 266:1564-1573.

Li, A.T. and D.J. Gray. 2003. Effect of five antimicrobial peptides on the growth of Agrobacterium tumefaciens, Escherichia coli and Xylella fastidiosa. Vitis 42:95-97.

Liu, Q., J. Ingersoll, L. Owens, S. Salih, R. Meng, and F. Hammerschlag. 2001. Response of transgenic Royal Gala apple (Malus $\times$ domestica Borkh.) shoots carrying a modified cecropin MB39 gene, to Erwinia amylovora. Plant Cell Rpt. 20:306-312.

Luby, J.J., J.R. Ballington, A.D. Draper, P. Kazimierz and M.E. Austin. 1991. Blueberries and cranberries (Vaccinium). Acta Hort. 290:491-546.

Maqbool, S.B.,S. Riazuddin, N.T.Loc,A.M.R.Gatehouse, and P. Christou. 2001. Expression of multiple insecticidal genes confers broad resistance against a range of rice pests. Mol. Breed. 7:85-93.

Mathews, H., W. Wagoner, J. Kellogg, and R. Bestwick. 1995. Genetic transformation of strawberry: Stable integration of a gene to control biosynthesis of eth- ylene. In Vitro Cell. Dev. Biol. 31:36-43.

Maas, J.L., M.R. Pooler, and G.J. Galletta. 1995. Bacterial angular leafspot disease of strawberry: present status and prospects for control. Adv. Strawberry Res. 14:18-24

Mills, D. and F.A. Hammmerschlag. 1993. Effect of cecropin B on peach pathogens, protoplasts, and cells. Plant Sci. 93:143-150.

Monila,A.,A. Segura, andF. Garcia-Olmedo. 1993.Lipid transfer proteins (nsLTPs) from barley and maize leaves are potent inhibitors of bacterial and fungal plant pathogens. FEBS Lett. 316:119-122.

Moreno, M., A. Segura, and F. Garcia-Olmeda. 1994. Pseudothionin-St1, a potato peptide active against potato pathogens. Eur. J. Biochem 223:135-139.

Nordeen, R.O., S.L. Sinden, J.M. Jaynes, and L.D. Owens. 1992. Activity of cecropin SB37 against protoplasts from several plant species and their bacterial pathogens. Plant Sci. 82:101-107.

Osborn, R.W., G.W. De Samblanx, K. Thevissen, I. Goderis, S. Torrekens, F. Van Leuven, S. Attenborough, S.B. Rees, and W.F. Broekaert. 1995. Isolation and characterization of plant defensins from seeds of Asteraceae, Fabaceae, Hippocastanaceae and Saxifagaceae. FEBS Lett. 368:257-262.

Owens, L. and T. Huette. 1997. A single amino acid substitution in the antimicrobial defense protein cecropin B is associated with diminished degradation by leaf intercellular fluid. Mol. Plant-Microbe Interact. 10:525-528.

Owens, C.L., M.F. Thomashow, J.F. Hancock, and A.F. Iezzoni. 2002. CBF1 orthologs in sour cherry and strawberry and the heterologous expression of $C B F 1$ in strawberry. J. Amer. Soc. Hort. Sci. 127:489-494.

Pooler, M.R., D.F. Ritchie, and J.S. Hartung. 1996. Genetic relationships among strains of Xanthomonas fragariae based on random amplified polymorphic DNA PCR, repetitive extragenic palindromic PCR, and enterobacterial repetitive intergenic consensus PCR data and generation of multiplexed PCR primers useful for the identification of this phytopathogen. Appl. Environ. Microbiol. 62:3121-3127.

Punja, Z.K. and S.H.T. Raharjo. 1996. Response of transgenic cucumber and carrot plants expressing different chitinase enzymes to inoculation with fungal pathogens. Plant Dis. 80:999-1005

Roberts, P.D., R.D. Berger, J.B. Jones, and C.K. Chandler. 1995. Epidemiology of Xanthomonas fragariae on strawberry: Yield loss and disease management. Phytopathology 85:1172.

Rowland, L.J. and F.A. Hammerschlag. 2003. Blueberry. In: R.E. Litz (ed.). Biotechnology of fruit and nut crops. CABI Publ., Wallinford. (in press).

Sharma, A., R. Sharma, M. Imamura, M. Yamakawa, and H. Machii. 2000. Transgenic expression of cecropin $\mathrm{B}$, an antibacterial peptide from Bombyx mori, confers enhanced resistance to bacterial leaf blight in rice. FEBS Lett. 484:7-11.

Stuiver, M.H. and J.H.H.V. Custers. 2001. Engineering disease resistance in plants. Nature 411:865-868.

Terras, F.R.G., H.M.E. Schoofs, M.R.C. De Bolle, F. Van Leuven, S.B. Rees, J. Vanderleyden, B.P.A. Cammue, and W.F. Broekaert. 1992. Analysis of two novel classes of antifungal proteins from radish (Raphanus sativus L.) seeds. J. Biol. Chem. 267:15301-15309

Terras, F.R.G., K. Eggermont, V. Kovaleva, N.V. Raikhel, R.W. Osborn, A. Kester, S.B. Rees, S. Torrekens, F. Van Leuven, J. Vanderleyden, B.P.A. Cammue, and W.F. Broekaert. 1995. Small cysteine-rich antifungal proteins from radish: Their role in host defense. Plant Cell 7:573-588.

Van Parijs, J., W.F. Broekaert, K.J. Goldstein, and W.J. Peumans. 1991. Hevein: An antifungal protein from rubber-tree (Hevea brasiliensis) latex. Planta 183:258-264.

Vigers, A.J., W.K. Roberts, and C.P. Selitrennikoff. 1991. A new family of plant antifungal proteins. Mol. Plant-Microbe Interact. 4:315-323.

Wilhelm, S. 1999. The california strawberry industry and soil fumigation. A review. Calif. Strawberry Comm., Watsonville. 